\title{
Pentastomid, Raillietiella mottae Almeida, Freire and Lopes, 2008, infecting lizards in an area of caatinga, northeast, Brazil
}

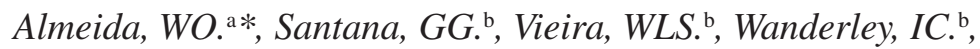 \\ Freire, EMX. ${ }^{\mathrm{c}}$ and Vasconcellos, $A .^{\mathrm{c}}$ \\ aDepartamento de Ciências Físicas e Biológicas, Universidade Regional do Cariri - URCA, \\ Rua Cel. Antônio Luiz, 1161, CEP 63105-000, Crato, CE, Brazil \\ 'Programa de Pós-Graduação em Ciências Biológicas (Zoologia), Laboratório Coleção de Herpetologia, \\ Departamento de Sistemática e Ecologia, Centro de Ciências Exatas e da Natureza - CCEN, \\ Campus I, Universidade Federal da Paraíba - UFPB, \\ Cidade Universitária, CEP 58059-900, João Pessoa, PB, Brazil \\ ${ }^{\mathrm{c}}$ Campus Universitário Lagoa Nova, Universidade Federal do Rio Grande do Norte - UFRN, \\ CEP 59072-970, Natal, RN, Brazil \\ *e-mail: walmeida@urca.br \\ Received October 13, 2006 - Accepted February 27, 2007 - Distributed May 31, 2008
}

(With 1 figure)

\begin{abstract}
Pentastomids can infect the respiratory tract of lizards, causing their death and as a result influencing the population size of hosts. Despite this, studies on rates of pulmonary infection of Brazilian lizards, including those living in Caatinga ecosystems of northeastern Brazil are scarce. Active collections of lizards were performed from October to December 2004 in an area of Caatinga of the Estação Experimental de São João do Cariri - EESJC $\left(07^{\circ} 25^{\prime}\right.$ S and $\left.36^{\circ} 30^{\prime} \mathrm{W}\right)$, located in the state of Paraíba, Northeast of Brazil. Forty-five lizards inhabiting granite outcrops in an area of Caatinga were captured, belonging to the following species: Tropidurus hispidus (Spix, 1825) (18 individuals), T. semitaeniatus (Spix, 1825) (15 individuals), Phyllopezus periosus Rodrigues, 1986 (6 individuals), and P. pollicaris (Spix, 1825) (6 individuals). Laboratory examination revealed that all species had some degree of pulmonary infection caused by Raillietiella mottae. The highest rates of prevalence (66.7\%) and mean intensity of infection $(5.25 \pm 2.01$, range of 2-11) were observed in P. periosus. The results obtained in this study show that lizards of the Brazilian semiarid region are infected by a generalist species of pentastomid. The most likely cause for such pattern is the similarity in lizards' diets (ants and termites). It is particularly noteworthy that T. semitaeniatus, P. periosus, and P. pollicaris represent new host records for $R$. mottae.
\end{abstract}

Keywords: Raillietiella, Pentastomida, Tropiduridae, Gekkonidae, neotropical region.

\section{Infecção por Pentastomida, Raillietiella mottae Almeida, Freire and Lopes, 2008, em lagartos de uma área de caatinga, nordeste do Brasil}

\begin{abstract}
Resumo
Pentastomídeos podem infectar o trato respiratório e até levar lagartos à morte e, por isso, exercem influência sobre o tamanho populacional de seus hospedeiros. Apesar disso, existem muito poucos trabalhos sobre as taxas de infecção pulmonar de lagartos brasileiros, sobretudo na região nordeste. Entre outubro e dezembro de 2004 foram realizadas coletas ativas em uma área de Caatinga localizada na Estação Experimental de São João do Cariri - EESJC $\left(07^{\circ} 25^{\prime}\right.$ S e $36^{\circ} 30^{\prime}$ W), localizada no estado da Paraíba, nordeste do Brasil. Quarenta e cinco lagartos foram capturados habitando afloramentos de granito (lajeiros): Tropidurus hispidus (18 indivíduos), T. semitaeniatus (15 indivíduos), Phyllopezus periosus (6 indivíduos) e $P$. pollicaris (6 indivíduos). Após o exame laboratorial ficou demonstrado que todas as espécies possuíam algum grau de infecção pulmonar causado por Raillietiella mottae. As maiores taxas de prevalência $(66,7 \%)$ e intensidade média de infecção $(5,25 \pm 2,01$, range 2-11) foram encontradas em P. periosus. Os resultados demonstram que a espécie de pentastomídeo que infecta lagartos é generalista e a sobreposição da dieta dos lagartos (formigas e térmites) aparentemente deve ser a fonte de infecção. Tropidurus semitaeniatus, P. periosus e P. pollicaris representam são registrados como novos hospedeiros para $R$. mottae.
\end{abstract}

Palavras-chave: Raillietiella, Pentastomida, Tropiduridae, Gekkonidae, região neotropical. 


\section{Introduction}

Brazil still holds one of the most significant biological diversities in the world, with a herpetofauna represented by a great number of species described (Rodrigues, 2005). A rich fauna of endoparasites is associated to reptiles, but much of the published work on these animals is mostly descriptive (Vicente et al., 1993; Rocha et al., 2000). Studies on community variables, like abundance, prevalence, and mean intensity of infection have only recently been published (Ribas et al., 1995; 1998; Rocha, 1995; Vrcibradic et al., 1999; Vrcibradic et al., 2000; Vrcibradic et al., 2002a; 2002b; Rocha et al., 2003; Rocha and Vrcibradic, 2003; Dias et al., 2005; Anjos et al., 2005).

Pentastomids are essentially parasites of reptiles' respiratory tract (Riley, 1986). In Brazil, except from one review and a few phylogenetic studies (Rego, 1984; Almeida and Christoffersen, 1999; 2002), research on these animals has been restricted to their occurrence and descriptions of new species (Motta, 1963a, b; Motta and Gomes, 1968; Rego, 1983; 1984; Almeida et al., 2006a,b; Almeida et al. 2008b; Rocha and Vrcibradic, 2003; Dias et al., 2005; Anjos et al., 2005). Also, only the pentastomid species Raillietiella freitasi (Motta and Gomes, 1968) was described as parasitizing the lungs of Mabuya punctata (Spix, 1825), a lizard of the Fernando de Noronha Island (Motta and Gomes, 1968).

Recent publications have included evaluations on infection rates, prevalence, and mean intensity of infection in studies of snakes, amphisbaenians and lizards of the northeastern region of Brazil (Dias et al., 2005; Almeida et al., 2006a; Almeida et al. 2006b; Almeida et al. 2007; Almeida et al. 2008a; Almeida et al. 2008b; Anjos et al., 2008), nevertheless, only four lizard species were investigated. Dias et al. (2005) reported a likely new species of Raillietiella aff. furcocerca (Diesing, 1863) infecting the lungs of two whiptail lizard species, Cnemidophorus abaetensis Dias, Rocha and Vrcibradic, 2002 and C. ocellifer (Spix, 1825) in a restinga habitat in the state of Bahia. Almeida et al. (2008b) investigated infection caused by $R$. mottae in the lungs of Tropidurus hispidus (Spix, 1825) living in the semi-arid region of Cariri, state of Ceará, northeastern Brazil. Anjos et al. (2008) reported Hemidactylus mabouia (Moreau de Jonnès, 1818), a dwelling's invader gecko in the Cariri region (municipality of Barbalha, Ceará state), as a new host of $R$. mottae. The authors reported in their work, the first occurrence in Brazil of $R$. frenatus Ali, Riley and Self, 1981 parasitizing $H$. mabouia.

In the present study we evaluate infections caused by pentastomids in an assemblage of lizards living in an area of Caatinga. It is specifically addressed here i) the composition of pentastomid fauna and ii) rates of infection (prevalence and intensity).

\section{Material and Methods}

Diurnal and nocturnal active lizards living on granite outcrops in the Caatinga were captured using sling- shots and through manual collection, from October to December 2004. The outcrops, locally known as "lajeiros', are situated in the Estação Experimental de São João do Cariri - EESJC ( $07^{\circ} 25^{\prime} \mathrm{S}$ and $\left.36^{\circ} 30^{\prime} \mathrm{W}\right)$, in the state of Paraíba, Northeast Brazil. The area where the animals were captured is characterized by xerophytic vegetation, with thorny shrubs, stunted trees with entwined branches, having high density of cacti and bromeliads (Mélo and Bandeira, 2004; Andrade et al., 2005). It is situated in the semi-arid region of Paraíba, characterized temperatures ranging between 28 and $35{ }^{\circ} \mathrm{C}$ on average and annual mean rainfall of $387 \mathrm{~mm}$. The rainfall concentrates from February to April. During drier years the dry period lasts over eight months (Núcleo de Meteorologia Aplicada, 1987).

Upon collection, the lizards were frozen-euthanized and their snout-vent length (SVL) measured with a ruler (to the nearest $1 \mathrm{~mm}$ ). They were then fixed in formalin $10 \%$ and preserved in ethanol $70 \%$.

The respiratory tracts of the lizards were removed and the search for pentastomids was carried out under a stereomicroscope. The pentastomids collected were cleared in Hoyer's medium, temporarily slide-mounted and preserved in ethanol $70 \%$. Identification was performed based on dimensions of the hooks and copulatory spiculae of males, with the aid of a microscope with a micrometric eyepiece (see Ali et al., 1984; 1985; Almeida et al., 2008b).

Each specimen was compared with vouchers of Raillietiella freitasi (Motta and Gomes, 1968) numbers 20420, 20421, 20429, 20431, 20432, 20434, 20439, $30325 a-c, 30326,30327,30328$, 30329a-c, 30330a-b provided by the Helminthological Collection of the Oswaldo Cruz Institute (CHIOC). After identification the material was deposited in the Zoological Collection of the Universidade Regional do Cariri (LZ-URCA) and labelled as Raillietiella mottae numbers 201-212. The eco-parasitological terms used in this study followed Bush et al. (1997).

\section{Results}

Forty-five lizards were captured, being 18 individuals of the species $T$. hispidus, 15 of $T$. semitaeniatus (Spix, 1825), 6 of P. periosus Rodrigues, 1986 , and 6 of $P$. pollicaris. All species had their lungs infected by only one species of pentastomid, $R$. mottae (Table 1; Figure 1). The highest rates of prevalence and mean intensity of infection were found in $P$. periosus.

\section{Discussion}

Almeida et al. (2008b), using data from literature reports, emphasized the possibility of specificity of $R$. mottae parasitizing $T$. hispidus, which had not yet been recorded as a host of any species of pentastomid. Almeida et al. (2008b) stated that together with morphological evidence, such evaluation would reinforce the proposition for the existence of a new species. However, 
Table 1. Epidemiological data of lizards (sample size in parentheses) and their respective pentastomid infection in an area of Caatinga, State of Paraíba. For each host species (overall and by species) it is shown the mean snout-vent length (SVL) (range in $\mathrm{mm}$ ), prevalence (in absolute values and proportions), and intensity of infection (mean \pm one standard deviation, with range in parentheses).

\begin{tabular}{lcccc}
\hline \multicolumn{1}{c}{ Host species (n) } & \multicolumn{1}{c}{$\begin{array}{c}\text { Mean SVL } \\
(\mathbf{m m})\end{array}$} & $\begin{array}{c}\text { Weight } \\
(\mathbf{g})\end{array}$ & $\begin{array}{c}\text { Prevalence } \\
(\boldsymbol{\%})\end{array}$ & $\begin{array}{c}\text { Mean intensity } \\
(\text { range })\end{array}$ \\
\hline Phyllopezus periosus (6) & $89.30 \pm 8.50(54-114)$ & $20.03 \pm 4.64(3.30-36.13)$ & $4(66.7)$ & $5.25 \pm 2.01(2-11)$ \\
Phyllopezus pollicaris (6) & $70.22 \pm 2.87(61-75.80)$ & $8.24 \pm 1.06(4.99-10.87)$ & $1(16.6)$ & 5.0 \\
Tropidurus hispidus $(18)$ & $77.04 \pm 4.21(32-112)$ & $20.68 \pm 3.27(5.51-54.70)$ & $2(11.1)$ & 1.0 \\
Tropidurus semitaeniatus (15) & $60.79 \pm 3.12(38.6-82)$ & $6.28 \pm 1.01(1.25-14.20)$ & $2(13.3)$ & $4.0 \pm 3.0(1-7)$ \\
\hline
\end{tabular}

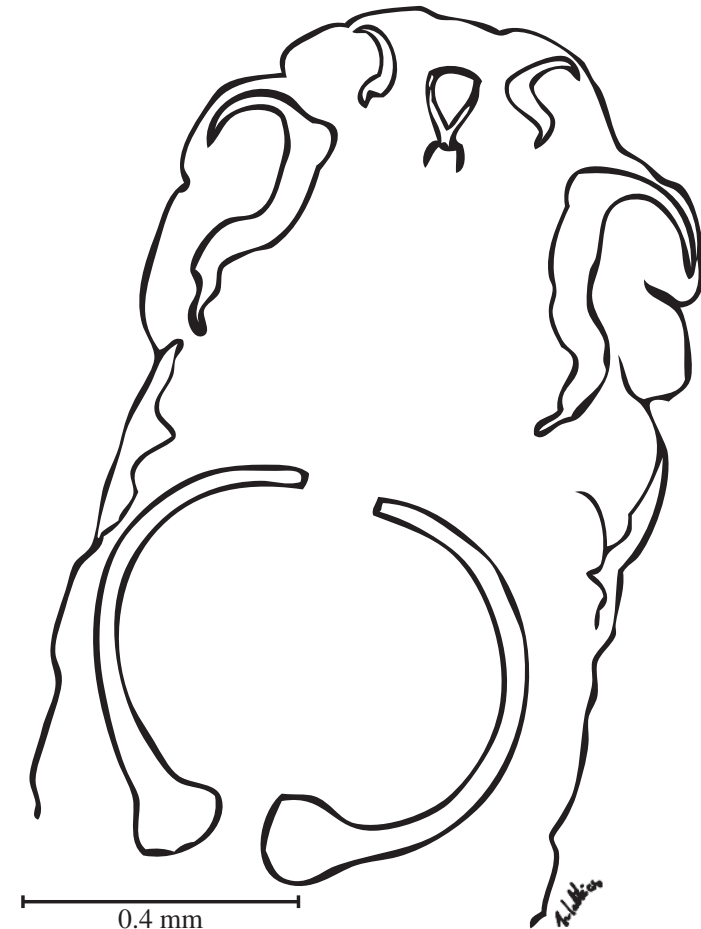

Figure 1. Raillietiella mottae: detail of the cephalothorax male (LZ-URCA n ${ }^{\circ}$ 0207) viewed ventrally with sharply tip pointed hooks and copulatory spiculae with tips curved or "C-shaped" knob-like projection base.

data obtained by Almeida et al. (2006a; 2008a; 2008b) indicates that two species of pentastomids, Cephalobaena tetrapoda Heymons, 1922 and Raillietiella furcocerca, should be generalists because of their recorded variety of hosts. Anjos et al. (2008) reported only one female of gecko, $H$. mabouia, parasitized by $R$. mottae. This isolated case reported by these above-mentioned authors could have resulted from the low sampling they performed.

The results obtained in the present study suggest that $R$. mottae is a generalist parasite and does not have any reptile specificity, at least with respect to the lizard species investigated. All lizards studied are insectivores and foragers, and therefore, could be deemed as predators with short handling times when compared to their search times. Searching is always moderately time consum- ing, so searchers should be generalists, a similar condition to the one of birds reported by Begon et al. (2006). Lizards would have an overall profitability maximized by a broader diet, constituted by minute insects thriving on outcrops of the Caatinga. Tropidurus hispidus and T. semitaeniatus are diurnal predators while P. periosus and $P$. pollicaris are nocturnal predators. Both groups (tropidurid and geckonid) feed on ants and termites that are abundant on Caatinga outcrops, as we could observe in situ, and they are likely intermediate hosts of R. mottae.

Among the prevalences found in the present study, the one of T. hispidus $(11.1 \%)$ is identical to prevalence value obtained by Almeida et al. (2008b). All other lizards investigated here showed a range of 13.3-16.6\%, close to prevalence values of $T$. hispidus, except the prevalence of $P$. periosus that showed a value of $66.7 \%$. Other results reported on pulmonary infection by pentastomids in lizards showed prevalence values lower than those obtained here, namely: Mabuya agilis Raddi, 1823 (3.6-9.0\%) (Vrcibradic et al., 2002b), Cnemidophorus abaetensis (6.0\%) (Dias et al., 2005), C. ocellifer (2.5\%) (Dias et al., 2005), and H. mabouia (9.1\%) (Anjos et al., 2008).

Differing values of rates of infection intensity were also obtained here. The lowest value was observed in T. hispidus (1.0). This value however, is close to the ones reported for pentastomids in lizards of other Brazilian ecosystems, namely: M. agilis (1.0), C. ocellifer (1.0) and $H$. mabouia $(1.8 \pm 1.4)$ (Vrcibradic et al., 2002b; Dias et al., 2005; Anjos et al., 2008). However, such values differed from those reported by Almeida et al. (2008b) for infection intensity of $R$. mottae in T. hispidus $(6.0 \pm 1.4$, range 5-7)

Rates of infection intensity obtained here for T. semitaeniatus $(4.0 \pm 3.0$, range $1-7)$ and $P$. pollicaris (5.0) and also the value of 4.5 obtained for $C$. abaetensis by Dias et al. (2005) are similar to values obtained by Almeida et al. (2008b).

The higher values of mean rates of infection recorded for $R$. mottae refer to $P$. periosus, which had mean rate of infection of $5.25( \pm 2.01$, range 2-11). According to Riley et al. (1991), burdens of 9-20 worms per host frequently killed geckos.

Despite all these discrepancies, it is important to emphasize that similarity and difference in rates of in- 
fection intensity may result from stochastic events and vary according to sample size and specific environmental characteristics from the studied areas. Therefore, it must be emphasized the need for further studies on patterns of pulmonary infection by pentastomids in lizards, in the neotropical region.

Acknowledgements - Our thanks to D. Noronha, curator of the Helminthological Collection of the Instituto Oswaldo Cruz, for the loan of pentastomid specimens; to FUNCAP - the Fundação Cearense de Apoio ao Desenvolvimento Científico e Tecnológico (Ref. 943/03 - Edital 003/03) for the research grant to W. O. Almeida; to the Conselho Nacional de Desenvolvimento Científico e Tecnológico $(\mathrm{CNPq})$ for the research grant received through the Programa Ecológico de Longa Duração (PELD); to the Fundação Coordenação de Aperfeiçoamento de Pessoal de Nível Superior (CAPES) for the scholarship to G. G. Santana. We also thank the Brazilian Institute for the Environment and Natural Resources (IBAMA) for permission to collect samples from protected areas (Documents nr 02021.000075/2006-7 and 080/04 - RAN/ IBAMA 02007.001009/04-73); to B. Grisi for the suggestions and the English version of the manuscript; to E. Medeiros (UEPB) for revising the English version of the text; and to two anonymous reviewers for their valuable suggestions and comments on the manuscript.

\section{References}

ALI, JH., RILEY, J. and SELF, JT., 1984. A revision of the taxonomy of pentastomid parasites (genus Raillietiella Sambon, 1910) from American snakes and amphisbaenias. Syst. Parasitol., vol. 6, p. 87-97.

ALI, JH., RILEY, J. and SELF, JT., 1985. A review of the taxonomy and systematics of the pentastomids genus Raillietiella Sambon, 1910 with a description of a new species. Syst. Parasitol., vol. 7, p. 111-123.

ALMEIDA, WO. and CHRISTOFFERSEN, ML., 1999. A cladistic approach to relationships in Pentastomida. J. Parasitol., vol. 85 , no. 4, p. 695-704.

-, 2002. Pentastomida. In MORRONE, J. and LLORENTEBOUSQUETS, J. (eds.). Biodiversidad, Taxonomía y Biogeografía de Artrópodos de México: Hacia una síntesis de su conocimiento, vol. 3. México: Universidad Nacional Autónoma de México. 690 p.

ALMEIDA, WO., BRITO, SV., FERREIRA, FS. and CHRISTOFFERSEN, ML., 2006a. First record of Cephalobaena tetrapoda (Pentastomida: Cephalobaenidae) as a parasite on Liophis lineatus (Ophidia: Colubridae) in Northeast Brazil. Braz. J. Biol. $=$ Rev. Bras. Biol., vol. 66, no. 2A, p. 559-564.

ALMEIDA, WO., FERREIRA, FS., BRITO, SV. and CHRISTOFFERSEN, ML., 2006b. Raillietiella gigliolii (Pentastomida) infecting Amphisbaena alba (Squamata, Amphisbaenidae): a first record for Northeast Brazil. Braz. J. Biol. $=$ Rev. Bras. Biol., vol. 66, no. 4, p. 29-41.

ALMEIDA, WO., VASCONCELLOS, A., FREIRE, EMX. and LOPES, SG., 2007. Prevalence and intensity of pentastomid infection in two species of snakes from Northeast Brazil. Braz. J. Biol. $=$ Rev. Bras. Biol., vol. 67, no. 1, p. 759-763.

ALMEIDA, WO., COSTA, TBG., FREIRE, EMX. and VASCONCELLOS, A., 2008a, Pentastomid infection in Philodryas nattereri Steindachner, 1870 and Oxybelis aeneus (Wagler, 1824) (Squamata: Colubridae) in a caatinga of
Northeastern Brazil. Braz. J. Biol. = Rev. Bras. Biol., vol. 68, no. 1, p. 193-197.

ALMEIDA, WO., FREIRE, EMX. and LOPES, SG., 2008b. A new species of Pentastomida infecting Tropidurus hispidus (Squamata: Tropiduridae) from caatinga in Northeastern Brazil. Braz. J. Biol. = Rev. Bras. Biol., vol. 68, no. 1, p. 199-203.

ANDRADE, LA., PEREIRA, IM., LEITE, UT. and BARBOSA, MRV., 2005. Análise da cobertura de duas fitofisionomias de caatinga, com diferentes históricos de uso, no município de São João do Cariri, Estado da Paraíba. Cerne, vol. 11, no. 3, p. 253-262.

ANJOS, LA., ALMEIDA, WO., VASCONCELLOS, A., FREIRE, EMX. and ROCHA, CFD., 2008. Pentastomids infecting an invader lizard, Hemidactylus mabouia (Gekkonidae) in Northeastern Brazil. Braz. J. Biol. = Rev. Bras. Biol., vol. 68, no. 4. [in press].

ANJOS, L., ROCHA CFD., VRCIBRADIC, D. and VICENTE, JJ., 2005. Helminths of exotic lizard Hemidactylus mabouia from a rock outcrop area in southeastern Brazil. J. Helmint., vol. 79 , no. 4 , p. 307-313.

BEGON, M., TOWNSEND, CR. and HARPER, JL., 2006. Ecology: from Individuals to Ecosystems. 4th ed. Oxford: Blackwell Publishing. 738 p.

BUSH, AO., LAFFERTY, KD., LOTZ, JM. and SHOSTAK, AW., 1997. Parasitology meets ecology in its own terms: Margulis et al. revisited. J. Parasitol., vol. 83, p. 575-583.

DIAS, EJR., VRCIBRADIC, D. and ROCHA CFD., 2005. Endoparasites infecting two species of whiptail lizards (Cnemidophorus abaetensis and $C$ ocellifer; Teiidae) in a restinga habitat of northeastern Brazil. Herpetol. J., vol. 15, p. 133-137.

MÉLO, ACS and BANDEIRA, AG., 2004. A quantitative and qualitative survey of termites (Isoptera) in an open shrubby caatinga in northeastern Brazil. Sociobiology, vol. 43, no. 3, p. 707-716.

MOTTA, CS., 1963a. Considerações sobre o gênero Raillitiella Sambon, 1910. Atas Soc. Biol. Rio de Janeiro, vol. 7, no. 2, p. $8-10$.

-, 1963b. Considerações sobre o gênero Cephalobaena Heymons, 1922 (Linguatulida), Cephalobaena tetrapoda. Atas Soc. Biol. Rio de Janeiro, vol. 7, no. 4, p. 7-8.

MOTTA, CS. and GOMES, DC., 1968. Sobre um novo gênero e uma nova espécie de Cephalobaenidae (Linguatulida, Cephalobaeniformia). Atas Soc. Biol. Rio de Janeiro, vol. 12, no. 1, p. 7-9.

NÚCLEO DE METEOROLOGIA APLICADA, 1987. Atlas climatológico da Paraíba. Campina Grande: Universidade Federal da Paraíba. 143 p.

REGO, AA., 1983. Pentastomídeos de répteis do Brasil: Revisão dos Cephalobaenidae. Mem. Inst. Oswaldo Cruz, vol. 78, no. 4, p. $399-411$.

-, 1984. Sinopse dos pentastomídeos da região neotropical. Garcia de Orta, Série Zoologia, vol. 11, p. 45-46.

RIBAS, SC., ROCHA, CFD., TEIXEIRA-FILHO, PF. and VICENTE, JJ., 1995. Helminths (Nematoda) of the lizard Cnemidophorus ocellifer (Sauria: Teiidae): assessing the effect of rainfall, body size and sex in the nematode infection rates. Cienc. Cult., vol. 47, no. 1-2, p. 88-91. 
-, 1998. Nematode infection in two sympatric lizards (Tropidurus torquatus and Ameiva ameiva) with different foraging tactics. Amphibia-Reptilia, vol. 19, p. 323-330.

RILEY, J., 1986. The biology of pentastomids. Adv. Parasitol., vol. 25, p. 45-128.

RILEY, J., POWELL, R. and SMITH, DD., 1991. Further observations of blunt-hooked pentastomids belonging to the genus Raillietiella Sambon, 1910 infecting Hemidactylus brookii (Sauria: Geckonidae) in Africa and the Caribbean; comparison with closely related Raillietiella spp. from an African skink (Mabuya perrotetii). Syst. Parasitol., vol. 20, p. 47-57.

ROCHA, CFD., 1995. Nematode parasites of the Brazilian sand lizard, Liolaemus lutzae. Amphibia-Reptilia, vol. 16, p. $412-415$.

ROCHA, CFD. and VRCIBRADIC, D., 2003. Nematode assemblages of some of some insular and continental lizard hosts of the genus Mabuya Fitzinger (Reptilia, Scincidae) along the eastern Brazilian coast. Revta Bras. Zool., vol. 20, no. 4, p. 755-759.

ROCHA, CFD., VRCIBRADIC, D. and ARAÚJO, AFB., 2000. Ecofisiologia de répteis de restingas brasileiras. In ESTEVES, FA. and LACERDA, LD. (eds.). Ecologia de Restingas e Lagoas costeiras. Macaé: NUPEM/ UFRJ.

ROCHA, CFD., VRCIBRADIC, D., VICENTE, JJ. and CUNHA-BARROS, M., 2003. Helminths infecting Mabuya dorsivittata (Lacertilia, Scincidae) from a high-altitude habitat in
Itatiaia National Park, Rio de Janeiro State, southeastern Brazil. Braz. J. Biol. = Rev. Bras. Biol., vol. 63, no. 1, p. 129-132.

RODRIGUES, MT., 2005. Conservação dos répteis brasileiros: os desafios para um país megadiverso. Megadiversidade, vol. 1, no. 1, p. 87-94.

VICENTE, JJ., RODRIGUES, HO., GOMES, DC. and PINTO, RM., 1993. Nematóides do Brasil, parte III: Nematóides de Répteis. Revta Bras. Zool., vol. 10, no. 1, p. 19-168.

VRCIBRADIC, D., ROCHA, CFD., RIBAS, SC. and VICENTE, JJ., 1999. Nematodes infecting the skink Mabuya frenata in Valinhos, São Paulo State, Southeastern Brazil. Amphibia-Reptilia, vol. 20, no. 3, p. 333-339.

VRCIBRADIC, D., CUNHA-BARROS, M., VICENTE, JJ., GALDINO, CAB., HATANO, FH., VAN-SLUYS, M. and ROCHA, CFD., 2000. Nematode infection patterns in four sympatric lizards from a restinga habitat (Jurubatiba) in Rio de Janeiro state, southeastern Brazil. Amphibia-Reptilia, vol. 21, no. 3, p. 307-316.

VRCIBRADIC, D., ROCHA, CFD., BURSEY, CD. and VICENTE, JJ., 2002a. Helminths infecting Mabuya agilis (Lacertilia, Scincidae) in a 'restinga' habitat (Grumari) of Rio de Janeiro, Brazil. Amphibia-Reptilia, vol. 23, no. 1, p. 109114.

-, 2002b. Helminth communities of two sympatric skinks (Mabuya agilis and Mabuya macrorhyncha) from two 'restinga' habitats in southeastern Brazil. J. Helminthol., vol. 76, no. 4, p. 355-361. 